\section{FEATURES OF CONFORMATION TYPE OF COWS BROWN CATTLE OF SUMY REGION ESTIMATED BY THE METHOD OF LINEAR CLASSIFICATION}

\author{
Khmelnychyi Leontiy Mykhailovych \\ Doctor of Agricultural Sciences, Professor \\ Sumy National Agrarian University \\ ORCID: 0000-0001-5175-1291 \\ E-mail: khmelnychy@ukr.net
}

\begin{abstract}
Researches cows firstborn of Lebedynsk, Ukrainian Brown dairy, Brown Swiss, estimated by the method of linear classification were carried out on livestock population in Sumy region. The interbreed variability was installed according to assessment by 100-score system of linear classification and by 18 descriptive traits of 9-score scale. Traits of dairy type were better expressed in cows of Swiss breed (83.5 score) against 80.4 and 81.8 scores in peers of Lebedynsk and Ukrainian Brown dairy. The traits of cows' body didn't differ in significant variability when comparing the tested breeds and were within the error of average value (83.6-83.9 scores). The average assessment of cows firstborn of Brown Swiss breed for udder morphological traits at the level of 83.1 scores exceeded animals assessments of Lebedynsk (80.4 scores) and Ukrainian Brown dairy (81.8 scores) breeds. Descriptive traits, in contrast to the group, have a significant level of variability, regardless of the assessed breed. High and reliable relationships were established between the assessment of group traits and the amount of milk yield during the first lactation, that characterize dairy type (0.222-0.433; $(P<0.001)$, body development $(0.392-0.412 ; P<0.001)$ and udder $(0.364-0.484 ; P<0.001)$. The correlation coefficients between the final assessment of type and milk yield in animals of the experimental breeds were in the range of 0.377-0.378 ( $P$ $<0.001)$. A positive correlation was observed for almost all individual descriptive traits of conformation and milk yield within the experimental breeds, with the exception of udder depth $(-0.119 \ldots-0.085)$, teat length $(-0.044 \ldots-0.115)$ and body condition $(-0.256 \ldots$ 0.303). According to the results of a linear assessment of Brown cows, the best indicators of conformation type were in Brown Swiss, characterizing it as a specialized dairy type. Lebedynsk cattle, according to the traits of linear classification, approached the combined type, and Ukrainian Brown dairy cattle occupied an intermediate position between scores of Lebedynsk and Swiss breeds with characteristic traits of dairy type.
\end{abstract}

Key words: Lebedynsk, Ukrainian dairy Brown, Swiss Brown, conformation type, linear classification, correlation, type DOI: https://doi.org/10.32845/bsnau.lvst.2020.2.1

In the early 80 s of the last century, the most common cattle in Sumy region was Lebedynsk breed. Most of the livestock population, as a result of reproductive crossing with Brown Swiss, was turned into a Ukrainian dairy breed.

The concept of creating new Ukrainian Brown dairy cattle provided obtaining an intermediate type of animals between the original breeds, which were distinguished by high milk yield and adaptability of Swiss breed, with objective advantages of parent breed concerning milk quality, high adaptive capacity, constitutional strength and productive longevity $[1,4,10]$.

In the summer of 2009, according to a joint order of the Ministry of Agrarian Policy of Ukraine and Ukrainian Academy of Agrarian Sciences (no. 386/59 dated 03.06.2009), Ukrainian Brown dairy breed of cattle was approved as a selection achievement of scientists and producers in Sumy region.

On the period of approbation, firstborn and full-age cows, record-holding cows, replacement young stock and herds of Ukrainian Brown dairy breed in general, including 2.146 cows, were estimated in seven basic farms. Average measurements that characterized the conformation of cows were: height at withers 132-137 cm; chest depth 67-74 cm; chest width 46-47 $\mathrm{cm}$; oblique body length $155-158 \mathrm{~cm}$; chest girth 190-195 centimeters.

The regional population of breeding animals in Sumy region was competitive in terms of milk productivity, structured lines, consolidated by conformation type, constitutionally strong, specialized dairy breed with sufficient capacity total area for further improvement as the selection method of breeding "in itself", and using best world gene pool in open population system $[5,6,8,9,22,23,24,36]$.

Вісник Сумського національного аграрного університету
The prospect of breeding Ukrainian Brown dairy breed cannot be imagined separately from the gene pool preservation of Lebedynsk cattle. There was no doubt that individual herds of this breed in Sumy region were a unique national treasure, since the value of genetic qualities inherent to the "Lebedynks" cannot be overestimated. They were well adapted to local feeding and housing conditions, have high viability, long-term use, selective plasticity, universal productivity, resistant to diseases, characterized by conformation and constitutional strength, they possessed a number of valuable biological features that were absent in animals of highly specialized breeds, and under wellcreated conditions it was possible to obtain high milk productivity.

Taking into account the current situation, it was necessary to improve it, therefore, a set of measures was taken to protect Lebedynsk breed, because its disappearance will lead to the depletion of genetic diversity and limit selection possibilities in improving the newly created breed.

The aim of research was: to study the original type of gene pool population of Lebedynsk cattle; the conformation of Ukrainian Brown dairy breed, obtained as a result of the combined variability of mother (Lebedynsk) and parental (Brown Swiss) breeds, to conduct a comparative analysis of the conformation of three Brown breeds, estimated by the method of linear classification, with determination of the variability of assessed type traits in their connection to the quantity of milk yield.

Materials and research methods. The conformation type was estimated in firstborn cows of Brown cattle of different origins in the leading farms of Sumy region. Estimation of con- 
formation type of firstborn cows was performed by the method of linear classification [25] according to the latest ICAR recommendations [7] at the age of 2-4 months after calving on two systems - 9-score, with a linear description of 18 conformation body parts and 100 - scoring system, taking into account four sets of conformation traits that characterize: severity of dairy type, body development, legs condition and morphological qualities of udder. Each set of conformation traits was assessed independently and had its own weighting factor in the total score of animal: dairy type - $15 \%$, body - $20 \%$; legs - $25 \%$ and udder $40 \%$.

The total score of type was determined by the formula:

$T S=(D T \cdot 0,15)+(B \cdot 0,20)+(L \cdot 0,25)+(U \cdot 0,40)$

Experimental indicators were processed by biometric statistics methods on a PC according to formulas of $E$. K. Merkur'eva [11].

Research results. Analysis firstborn cows of Brown cattle according to the 100 -score system of linear classification showed significant variability of its indicators within the controlled breeds, Table 1.

The group of conformation body parts, that characterize the dairy type of cows, was better expressed in the firstborn of
Swiss breed ( 83.5 scores) against 80.4 and 81.8 in the peers of Lebedynsk and Ukrainian Brown dairy, reliability of difference of 3.1 and 1.7 scores in these comparisons was high $(P<0.001)$.

Estimates of conformation traits, which together determined the body development of firstborn cows, did not differ significantly variability when comparing of experimental breeds and were within the error of average value (83.6-83.9 scores). A fairly high level of scores for traits body group of cows in the age of first lactation testified about their ability to consume large amounts of roughage and process them into products.

Estimation of linear traits that characterize the condition of legs was very important in the selection sense due to the fact that modern conditions of industrial complexes with hard coating and excessive moisture resulted in serious complications and pathology of cow legs. Studies [18, 19, 29, 30, 32] found that cows with high scores of linear traits that characterize strength of legs, distinguished by high indicators of milk productivity and duration of productive life. Therefore, the task of selection was to minimize the negative impact of harmful conditions of dairy complexes on the legs of animals through selection of animals with strong limbs.

Characteristics of Brown cattle firstborn cows of various origins according to linear assessment of the conformation type, scores

\begin{tabular}{|c|c|c|c|c|c|c|c|}
\hline \multirow{2}{*}{\multicolumn{2}{|c|}{ Conformation trait }} & \multicolumn{2}{|c|}{ Lebedynsk breed } & \multicolumn{2}{|c|}{ Ukrainian Brown dairy breed } & \multicolumn{2}{|c|}{ Swiss breed } \\
\hline & & $x \pm$ S.E. & $\mathrm{Cv}, \%$ & $x \pm$ S.E. & $\mathrm{Cv}, \%$ & $x \pm$ S.E. & $\mathrm{Cv}, \%$ \\
\hline \multicolumn{2}{|l|}{ Estimated animals } & \multicolumn{2}{|c|}{145} & \multicolumn{2}{|c|}{188} & \multicolumn{2}{|c|}{89} \\
\hline \multicolumn{2}{|l|}{$\begin{array}{l}\text { Set of traits: } \\
\text { dairy type }\end{array}$} & $80,4 \pm 0,11$ & 1,62 & $81,8 \pm 0,12$ & 1,44 & $83,5 \pm 0,24$ & 1,35 \\
\hline \multicolumn{2}{|l|}{ body } & $83,7 \pm 0,12$ & 1,23 & $83,9 \pm 0,10$ & 2,18 & $83,6 \pm 0,19$ & 1,83 \\
\hline \multicolumn{2}{|l|}{ legs } & $83,5 \pm 0,16$ & 1,55 & $82,7 \pm 0,17$ & 1,83 & $81,9 \pm 0,24$ & 1,74 \\
\hline \multicolumn{2}{|l|}{ udder } & $80,4 \pm 0,22$ & 2,23 & $82,2 \pm 0,24$ & 2,47 & $83,1 \pm 0,31$ & 2,15 \\
\hline \multicolumn{2}{|l|}{ Total score } & $81,3 \pm 0,18$ & 1,84 & $82,7 \pm 0,16$ & 1,92 & $83,4 \pm 0,21$ & 1,64 \\
\hline \multicolumn{2}{|c|}{ Descriptive traits: height } & $6,1 \pm 0,19$ & 24,4 & $6,5 \pm 0,13$ & 21,3 & $6,8 \pm 0,17$ & 20,4 \\
\hline \multicolumn{2}{|l|}{ chest width } & $7,8 \pm 0,11$ & 14,7 & $7,9 \pm 0,11$ & 14,8 & $7,7 \pm 0,16$ & 12,2 \\
\hline \multicolumn{2}{|l|}{ body depth } & $7,9 \pm 0,14$ & 12,7 & $8,1 \pm 0,13$ & 14,2 & $8,2 \pm 0,17$ & 12,5 \\
\hline \multicolumn{2}{|l|}{ angularity } & $5,2 \pm 0,19$ & 17,9 & $6,6 \pm 0,17$ & 15,4 & $7,5 \pm 0,14$ & 12,1 \\
\hline \multicolumn{2}{|l|}{ rump angle } & $5,9 \pm 0,12$ & 18,3 & $5,5 \pm 0,12$ & 18,2 & $5,1 \pm 0,12$ & 11,7 \\
\hline \multicolumn{2}{|l|}{ rear width } & $5,5 \pm 0,15$ & 17,4 & $5,7 \pm 0,13$ & 16,3 & $5,9 \pm 0,13$ & 14,2 \\
\hline \multicolumn{2}{|c|}{ angle of pelvic limbs } & $5,4 \pm 0,14$ & 18,3 & $5,1 \pm 0,11$ & 18,2 & $5,8 \pm 0,14$ & 16,3 \\
\hline \multicolumn{2}{|c|}{ pelvic limb posture } & $6,5 \pm 0,17$ & 16,1 & $6,8 \pm 0,18$ & 19,4 & $6,3 \pm 0,19$ & 17,2 \\
\hline \multicolumn{2}{|l|}{ hoof angle } & $5,9 \pm 0,11$ & 14,4 & $5,8 \pm 0,08$ & 16,3 & $4,7 \pm 0,18$ & 15,1 \\
\hline \multirow{2}{*}{$\begin{array}{l}\text { udder } \\
\text { attachment }\end{array}$} & front & $5,3 \pm 0,25$ & 26,8 & $6,7 \pm 0,18$ & 22,5 & $7,4 \pm 0,13$ & 14,3 \\
\hline & rear & $5,1 \pm 0,15$ & 19,3 & $5,9 \pm 0,12$ & 23,3 & $6,8 \pm 0,15$ & 14,9 \\
\hline \multicolumn{2}{|c|}{ central ligament } & $5,8 \pm 0,21$ & 24,7 & $6,2 \pm 0,17$ & 25,1 & $6,8 \pm 0,21$ & 18,3 \\
\hline \multicolumn{2}{|l|}{ udder depth } & $5,2 \pm 0,19$ & 20,2 & $6,4 \pm 0,13$ & 18,6 & $7,2 \pm 0,16$ & 15,4 \\
\hline \multirow{2}{*}{$\begin{array}{l}\text { teats } \\
\text { position }\end{array}$} & front & $4,3 \pm 0,26$ & 30,5 & $5,4 \pm 0,19$ & 27,5 & $6,7 \pm 0,22$ & 21,2 \\
\hline & rear & $4,1 \pm 0,22$ & 27,4 & $5,2 \pm 0,17$ & 25,6 & $6,6 \pm 0,20$ & 22,3 \\
\hline \multicolumn{2}{|l|}{ teats length } & $6,7 \pm 0,24$ & 19,3 & $5,6 \pm 0,18$ & 21,3 & $5,2 \pm 0,12$ & 17,1 \\
\hline \multicolumn{2}{|c|}{ body condition score } & $7,5 \pm 0,14$ & 13,7 & $6,4 \pm 0,13$ & 18,5 & $5,5 \pm 0,14$ & 16,2 \\
\hline \multicolumn{2}{|l|}{ locomotion } & $7,1 \pm 0,11$ & 12,9 & $6,8 \pm 0,14$ & 17,3 & $6,7 \pm 0,13$ & 12,4 \\
\hline
\end{tabular}

The best in terms of legs condition, according to the assessment of group traits that characterize them, were firstborn cows of Lebedynsk breed (83.5 scores) with a difference in its favor compared with the same age of Ukrainian Brown dairy cows by 0.8 scores and Brown Swiss - 1.6 scores $(P<0.001)$. This testified about conformation and constitutional strength of the Lebedynsk animal cattle.

The group of linear traits that characterize the dairy sys- tem was at this stage of selection and use of cows in modern mechanized conditions the most important among others. Not only productivity of cows, but also manufacturability and durability depended on the udder development, as evidenced by scientific studies conducted in this direction [20, 28, 33, 40, 42].

The average score of firstborn cows of Brown Swiss breed on morphological traits that characterize the udder, at the level of 83.1 scores, indicated about fairly high level of the chest 
development. Animals of Lebedynsk breed with estimation in 80.4 scores were inferior to peers of Ukrainian Brown dairy breed by 1.8 scores $(P<0.001)$, and Brown Swiss - by 2.7 scores $(P<0.001)$. This situation required breeders continue to work towards improving the morphological traits of udder in cows of Lebedynsk breed. This will not only improve its manufacturability, but also increase the milk productivity of cows, as there was a positive correlation between the udder linear traits and milk productivity [17, 36, 41, 43].

Generalized, according to results of linear classification of four sets conformation traits, final assessment in 83.4 scores of Brown Swiss showed a better degree of expression of their conformation type exceeding the same indicator of Lebedynsk (by 2.1 scores; $P<0.001)$ and Ukrainian Brown dairy cattle $(0.7$ scores; $P<0.01)$. Therefore, the further use of Brown Swiss sires of foreign selection will allow in the future improve Ukrainian Brown dairy breed both in terms of conformation type and milk productivity.

Worth noting the importance of using a linear classification of dairy cattle on a 100-score system within the respective four groups of linear traits belonging to one specific area. This assessment made it possible to characterize the body structure in a holistic harmonious combination of descriptive traits. In addition, it was necessary to compare the conformation type of assessed individual with the model cow of corresponding breed.

An objective understanding about development of important body parts of the cows conformation, which have a breeding value, separately from group ones, was made possible by a descriptive system of linear classification. According to this system, ICAR approved [7, 31] conformation traits were described, included to the characteristics of group traits of dairy type, body, legs and udder, taking into account a certain list of deficiencies most common in dairy cattle. In assessing animals on a 9-score scale, the mean severity of trait was rated at five scores, and biological deviations toward deteriorating development with a decrease in score to one, and conversely, if the development of trait was better, the score increased to nine. However, a maximum score of 9 did not always characterize the desired type of body parts development. This applied to such traits as rear position, hock joint angle, udder depth, position and teats length, the desired development of which was equal to 5 scores.

Descriptive traits, in contrast to the group, differ in a sig- nificant level of variability, regardless of the assessed breed. The limit of variability with coefficients of variation in the range of $12.7-30.5 \%$ was set for cows of Lebedynsk cattle, $14.2-27.5 \%$ - for Ukrainian Brown dairy and 11.7-22.3\% for Swiss breeds. The slightly lower level of variability of descriptive traits in Swiss animals indicated their higher consolidation by type, and the higher scores indicated better development of the conformation body parts, that ultimately formed the final score.

In general, the high phenotypic variability of assessment indicators for condition of descriptive traits development, especially height, angularity, rump angle, front and rear udder parts attachment, central ligament, udder depth and teats position in cows of Lebedynsk and Ukrainian Brown dairy breeds indicated the need for systemic selection on these grounds in the direction of their consolidation.

The firstborn cows of Brown Swiss with a significant difference prevailed peers of Lebedynsk breed on the following descriptive traits: height - by 0.7 scores $(P<0.05)$, angularity by 2.3 scores $(P<0.001)$, rear width - by 0,4 scores $(P<0.05)$, attachment of front -2.1 scores $(P<0.001)$ and rear udder parts - 1.7 scores $(P<0.001)$, central ligament - 1.0 scores $(P$ $<0.001)$, udder depth - by 2.0 scores $(P<0.001)$, front and rear teats position, respectively - by 2.4 and 2.5 scores $(P<0.001)$, yielding to the hoof angle by 1.2 scores $(P<0.001)$, fatness - by 2.0 scores $(P<0.001)$ and locomotion - by 0.4 scores $(P<0.05)$. Animals of Ukrainian Brown dairy breed, according to descriptive traits, usually occupied an intermediate place between the Lebedynsk and Swiss breeds.

Since the conformation was the most important component of constitutional and external its manifestation, this feature in the practice of selection was considered in all complexity of relationship with productive qualities of animals. For many years of improving cattle, accumulated numerous information about magnitude and direction of relationships between a number of body parts of the conformation and milk productivity cows of different breeds both in our country and abroad $[2,3,12,13,14$, $15,16,17,21,27,28,41,43]$.

The relationship between linear conformation traits and milk productivity in general and milk yield in particular was the most studied. Correlations between individual sets of conformation traits and the final assessment of 100 -score system of linear classification and individual descriptive traits and milk yield are given in table 2 .

Table 2

Correlation between indicators of linear estimation and value of milk yield cows firstborn of Brown breeds

\begin{tabular}{|c|c|c|c|c|c|c|}
\hline \multirow{2}{*}{ Trait } & \multicolumn{2}{|c|}{ Lebedynsk } & \multicolumn{2}{|c|}{ Ukrainian Brown dairy } & \multicolumn{2}{|c|}{ Swiss } \\
\hline & $\mathrm{r}$ & $t_{r}$ & $r$ & $\mathrm{t}_{\mathrm{r}}$ & $r$ & $t_{r}$ \\
\hline Estimated animals & \multicolumn{2}{|c|}{145} & \multicolumn{2}{|c|}{188} & \multicolumn{2}{|c|}{89} \\
\hline $\begin{array}{l}\text { Set of traits: } \\
\text { dairy type }\end{array}$ & 0,222 & 5,21 & 0,375 & 4,94 & 0,433 & 5,7 \\
\hline body & 0,392 & 3,93 & 0,426 & 4,77 & 0,412 & 4,44 \\
\hline legs & 0,116 & 1,22 & 0,232 & 3,45 & 0,241 & 2,42 \\
\hline udder & 0,364 & 5,13 & 0,456 & 7,74 & 0,484 & 4,72 \\
\hline Total score & 0,377 & 5,64 & 0,455 & 7,62 & 0,478 & 4,51 \\
\hline $\begin{array}{l}\text { Descriptive traits: } \\
\text { height }\end{array}$ & 0,258 & 2,97 & 0,284 & 4,56 & 0,301 & 3,33 \\
\hline chest width & 0,245 & 2,84 & 0,331 & 4,12 & 0,212 & 2,64 \\
\hline body depth & 0,314 & 5,4 & 0,269 & 3,94 & 0,359 & 4,32 \\
\hline angularity & 0,302 & 4,32 & 0,383 & 4,84 & 0,422 & 4,79 \\
\hline rump angle & 0,104 & 1,32 & 0,095 & 1,45 & 0,074 & 1,11 \\
\hline rear width & 0,224 & 2,88 & 0,266 & 3,98 & 0,289 & 3,29 \\
\hline angle of pelvic limbs & 0,122 & 1,97 & 0,177 & 1,87 & 0,227 & 2,79 \\
\hline
\end{tabular}

Вісник Сумського національного аграрного університету

Серія «Тваринництво», випуск 2 (41), 2020 


\begin{tabular}{|c|c|c|c|c|c|c|c|}
\hline \multirow{2}{*}{\multicolumn{2}{|c|}{ Trait }} & \multicolumn{2}{|c|}{ Lebedynsk } & \multicolumn{2}{|c|}{ Ukrainian Brown dairy } & \multicolumn{2}{|c|}{ Swiss } \\
\hline & & $r$ & $t_{r}$ & $r$ & $t_{r}$ & $r$ & $t_{r}$ \\
\hline \multicolumn{2}{|c|}{ pelvic limb posture } & 0,195 & 2,71 & 0,201 & 2,87 & 0,244 & 2,97 \\
\hline \multicolumn{2}{|l|}{ hoof angle } & 0,025 & 0,47 & 0,074 & 0,68 & 0,118 & 1,98 \\
\hline \multirow{2}{*}{$\begin{array}{l}\text { udder } \\
\text { attachment }\end{array}$} & front & 0,269 & 2,63 & 0,387 & 5,47 & 0,414 & 5,13 \\
\hline & rear & 0,241 & 2,58 & 0,303 & 6,27 & 0,442 & 4,17 \\
\hline \multicolumn{2}{|c|}{ central ligament } & 0,218 & 2,59 & 0,332 & 4,66 & 0,377 & 4,66 \\
\hline \multicolumn{2}{|l|}{ udder depth } & $-0,129$ & 1,24 & $-0,119$ & 1,45 & $-0,085$ & 0,93 \\
\hline \multirow{2}{*}{$\begin{array}{l}\text { teats } \\
\text { position }\end{array}$} & front & $-0,065$ & 1,51 & $-0,124$ & 2,23 & $-0,102$ & 1,98 \\
\hline & rear & 0,025 & 1,33 & 0,056 & 1,24 & 0,028 & 0,77 \\
\hline \multicolumn{2}{|l|}{ teats length } & $-0,044$ & 0,87 & $-0,115$ & 1,57 & $-0,078$ & 0,85 \\
\hline \multicolumn{2}{|c|}{ body condition score } & $-0,256$ & 2,86 & $-0,284$ & 3,05 & $-0,303$ & 3,54 \\
\hline \multicolumn{2}{|l|}{ locomotion } & 0,302 & 3,41 & 0,285 & 2,76 & 0,312 & 3,32 \\
\hline
\end{tabular}

The fact that shapes of body structure and development of individual body parts of animals reflected the nature of their physiological activity and direction of productivity was evidenced by positive correlation coefficients between linear traits of conformation type and amount of milk yield for first lactation. The highest and most reliable relationships were found by assessing group traits that characterize dairy type of cows, body and udder development, with correlation coefficients that were in animals of experimental breeds with variability of $0.222-0.433$, respectively $(P<0.001) ; 0.392-0.412(P<0.001) ; 0.364-0.484$ ( $P$ $<0.001)$ and with a final type score $(r=0.377-0.378$; $P<0.001)$. The group of traits that characterized condition of legs correlated with milk yield with slightly less variability $(r=0.116-0.241)$ and varying degrees of reliability. Higher correlation coefficients between group traits and milk yield during the first lactation were obtained in Swiss Brown cows.

A positive correlation was observed for almost all individual descriptive traits of conformation and milk yield of cows firstborn within the experimental Brown breeds, except position and teats length, udder depth, and fatness.

The overall indicator of body structure development height, almost at the same level correlated with volume of milk yield cows firstborn of all three experimental breeds $(r=0,258 \ldots$ 0,301).

In scientific studies reported conflicting data on the existence of correlation between chest width and milk yield per lactation. According to the authors [43], genetic and phenotypic correlations between these traits in Friesian $\times$ Bunai cows were 0.349 and 0.178 , respectively. While another group of scientists [26], in the study of Holstein cows of Czech selection, did not establish a relationship between chest width and milk yield, as the genetic correlation between these traits was only $0.02 \pm$ 0.04 . The level of correlations between chest width and milk yield volume in cows of Brown cattle in Sumy region of different origin corresponded to results of scientists [26], ranging from 0.258 in cows of Lebedynsk breed to $0.331(P<0.05)$ in Ukrainian Brown dairy cattle.

Angularity is one of the first descriptive traits, a high score for which characterized a good dairy type of cows, so the positive relationship between angularity and milk yield has a logical explanation $(r=0.302-0.422)$.

Repeatedly reported that lifetime and productive use of dairy cattle in industrial technology depended on the strength of pelvic limbs, which was determined by assessing hock joint angle and hoofs, and their posture [27, 28, 42]. In our studies, posture of pelvic limbs $(r=0.195-0.244)$ moderately positively correlated with milk yield, with a slightly lower coefficients pelvic limbs angle $(r=0.122-0.227)$ and with sufficiently low coefficients - hoofs angle $(r=0.024-0.118)$.

Numerous reports of scientific publications showed the existence of relationship different direction and strength between linear assessment of udder morphological traits and milk productivity of cows of different breeds [3, 12, 17, 21, 26, 27, 34, $37,39,43]$. Therefore, in the process of improving dairy cattle by udder structure, the selection value had those traits that directly affected on the productivity of animal, so selection of animals to improve them will significantly accelerate the efficiency of breeding for milk productivity. In this regard, it was important to determine in what extent the assessment for udder descriptive traits will correlate with milk yield per lactation.

The most important udder traits, which not only correlated with milk productivity, but their development will depend on lifetime and productive use, health and convenience of milking $[20,28,33,40,42]$.

The attachment of front udder part was assessed by the angle formed at the junction of udder with abdomen. Strength of udder attachment the most desirable development of trait was rated by highest score. The best development of this body part was characterized by the gradual transition of glandular tissue of udder into the abdomen by connecting lateral ligaments with formation of an obtuse angle. The strength udder attachment prevented him to sag with age. According to estimates of this trait, animals of the experimental breeds were closely correlated with amount of milk yield, especially Swiss $(r=0.414)$ and Ukrainian Brown dairy breeds $(r=0.387)$.

A similar task of linear trait-rear udder attachment, performing supporting function of udder at an appropriate height. This feature was especially important in the detection of a moderate relationship with amount of milk yield per first lactation in cows of Lebedynsk breed $(r=0.241)$, close - Brown Swiss $(r=$ $0.442)$ and Ukrainian Brown dairy breed $(r=0.303)$.

The importance of choosing the trait of central udder ligament in the system of linear classification was, first of all, in its supporting function. In the second, the value of central ligament was enhanced by correlation of its estimate with amount of milk yield per lactation, from 0.218 in Lebedynsk breed, to 0.377 in Brown Swiss breed.

That is, the selection of cows on these three linear udder traits will significantly improve its technological qualities and, due to the existence of positive correlation, will indirectly increase milk productivity of animals.

The udder depth was essential for selection of dairy cattle, the assessment for condition of which will depend on the conditional distance between the udder bottom and hock joint, both in terms of its suitability for machine milking technology and strength of attachment. The lowered udder below the hock 
joint in the age of first lactation dropped even lower with age, which created preconditions for its injury. Cows with low lowered udder exposed to pollution and other sources of litter, which would lead to the disease of clinical mastitis and increase in the number of somatic cells in milk $[35,38]$. Therefore, the desired correlation between this indicator and milk yield should be positive. A negative correlation between udder depth and milk yield with a variability of -0.129 in cows of Lebedynsk breed to -0.085 in Brown Swiss meant that udder in highly productive animals weighing large amounts of milk tended to drop. About negative correlation between udder depth and milk yield have been reported in other studies of dairy cows [42].

A negative and reliable phenotypic correlation between fatness and milking was found in cows of all three Brown breeds with variability from -0.256 (Lebedynsk cattle) to -0.303 (Brown Swiss breed) showing that high-yielding cows are not overfed. Similar data were obtained in the study of genetic correlations between fatness and milk yield by other authors with variability of -0.340 [43] and -0.465 [26].

According to assessment of locomotion's trait in correlation with milk yield, cows firstborn of the experimental breeds did not differ by significant variability for correlation coefficients between these traits $(r=0.285-0.312)$.

Summarizing results of linear assessment of Brown cow breeds in Sumy region, it was found that the best indicators of conformation type appeared in cows of Brown Swiss breed, that characterize it as a specialized dairy. Lebedynsk cattle for traits of linear classification approaching to combined type and Ukrainian Brown dairy, in most cases, occupied an intermediate position between estimates of Lebedynsk and Brown Swiss breeds, with characteristic traits of dairy type.

\section{Conclusions}

1. A comparative analysis of indicators linear classification firstborn cows of Brown breeds in Sumy region has shown the best expressiveness of conformation type by traits of body structure and udder at animals of Brown Swiss breed.

2. The determined high level of variability in the development of descriptive traits of the conformation indicated the need for careful selection of Brown cows, previously assessed by the method of linear classification.

3. The existence of a positive relationship between linear traits and milk yield in the selection of cows by type will indirectly increase milk production capacity of animals.

\section{References:}

1. Burkat, V. P., Kotendzhi, G. P. and Ladyka, V. I., 1991. Metody selektsii lebedinskogo skota na sovremennom etape [Breeding methods of Lebedinsky cattle at the present stage]. New methods of selection and biotechnology in animal husbandry, Proceedings of the research and production conference, Kiev, pp. 118-120.

2. Burkat, V. P., Polupan, Yu. P. and Yovenko, I. V., 2004. Liniina otsinka koriv za typom [Linear estimation of cows by type]. Kyiv: Ahrarna nauka.

3. Hrinkevych, L. Z., 2004. Vzaiemozviazok mizh produktyvnistiu i morfofunktsionalnymy vlastyvostiamy vymeni koriv holshtynizovanoho typu chervonoi molochnoi porody [Relationship between productivity and morphofunctional traits of udder of Holsteinized cows of Red dairy breed]. Tavriiskyi naukovyi visnyk. Kherson, issue 36, pp. 101-104.

4. Ladyka, V. I. 2004., Metody stvorennia, suchasnyi stan ta shliakhy podalshoho udoskonalennia buroi molochnoi porody. Derzhavna knyha pleminnykh tvaryn burykh porid velykoi rohatoi khudoby [Methods of creation, current state and ways of further improvement of Brown dairy breed. State book of breeding animals Brown cattle breeds]. Kyiv: „PPNV”.

5. Ladyka, V. I., Pavlenko, Yu. M. and Sukharieva, A. V., 2017. Vplyv liniinoi nalezhnosti na riven produktyvnosti koriv ukrainskoi buroi molochnoi porody [Influence of linear affiliation on the productivity level of Ukrainian Brown dairy cows]. Visnyk Sumskoho NAU: seriia "Tvarynnytstvo", issue 7(33), pp. 72-77.

6. Ladyka, V. I. and Khmelnychyi, L. M., 2018. Osoblyvosti fenotypovoi riznomanitnosti koriv za eksteriernym typom v aspekti zberezhennia henofondu buroi khudoby [Features phenotypic diversity cow's conformation type in the aspect of preserving the gene pool of Brown cattle]. Visnyk Sumskoho NAU: seriia "Tvarynnytstvo", issue 2(34), pp. 3-10.

7. Ladyka, V. I., Khmelnychyi, L., Burkat, V. P. and Ruban, Yu. D., 2010. Reiestratsiia ICAR: Dovidnyk [ICAR Registration: Reference book]. Sumy.

8. Ladyka, V., Kotendzhi, H., Rubtsov, I. [et al.]. 2007. Ukrainska bura molochna poroda [Ukrainian Brown dairy breed]. Tvarynnytstvo Ukrainy, no. 2, pp. 37-40.

9. Ladyka, V. I. and Khmelnychyi, L. M., 2007. Pleminnu otsinku - na zahalnoderzhavnyi riven [Pedigree assessment - at national level]. Tvarynnytstvo Ukrainy, no. 2, pp. 10-11.

10. Ladyka, V.I., 2000. Stan ta perspektyvy selektsii buroi khudoby [Status and prospects of breeding Brown cattle]. Visnyk ahrarnoi nauky, issue12, pp. 84-86.

11. Merkur'eva, E. K., 1977. Geneticheskie osnovy selektsii v skotovodstve [Genetic bases of selection in livestock]. Moskva: Kolos.

12. Polupan, Yu. P., 2013. Ontogenetic and breeding regularities formation of economically useful traits of Dairy cattle. Doctor's thesis of Agricultural sciences. Institute of Animals breeding and Genetics NAAS, Chubynske.

13. Polupan, Yu. P. and Koval, T. P., 2006. Zviazok morfolohichnykh osoblyvostei vymia koriv chervonoi molochnoi khudoby z yikhnoiu molochnoiu produktyvnistiu [Relationship between udder morphological features of Red dairy cows and their milk productivity]. Visnyk ahrarnoi nauky, no. 11, pp. 49-52.

14. Khmelnychyi, L. M., 2018. Uspadkovuvanist ta koreliatsiina minlyvist liniinykh oznak eksterieru koriv-pervistok ukrainskoi chervono-riaboi molochnoi porody Cherkashchyny [Heritability and correlation variability of linear conformation traits cows firstborn Ukrainian Red-and-White dairy breed of Cherkasy region]. Naukovo-informatsiinyi Visnyk Khersonskoho derzhavnoho ahrarnoho universytetu. Kherson, issue 11, pp. 73-75. 
15. Khmelnychyi, L. M., 2018. Formuvannia eksteriernoho typu koriv ukrainskoi chervono-riaboi molochnoi porody za vykorystannia buhaiv-plidnykiv, otsinenykh za metodykoiu liniinoi klasyfikatsii [Formation of conformation type cows of Ukrainian Redand-White dairy breed with the use of sires, estimated by the method of linear classification]. Visnyk Sumskoho natsionalnoho ahrarnoho universytetu. Seriia "Tvarynnytstvo», issue 2(34), pp. 10-20.

16. Khmelnychyi, L. M. and Vechorka, V. V., 2014. Vikova minlyvist koreliatsii mizh nadoiem ta liniinoiu otsinkoiu typu korivpervistok ukrainskykh chorno- ta chervono-riaboi molochnykh porid [Age variability of correlations between milk yield and linear assessment of type cows firstborn of Ukrainian Black- Red-and-White dairy breeds]. Tekhnolohiia vyrobnytstva i pererobky produktiv tvarynnytstva. Zbirnyk naukovykh prats BNAU. Bila Tserkva, no. 1(116), pp. 84-87.

17. Khmelnychyi, L. M. and Vechorka, V. V., 2020. Influence of linear conformation traits on the state of milk productivity cows firstborn of Ukrainian Black- and Red-and-White dairy breeds [Vplyv liniinykh oznak eksterieru na stan molochnoi produktyvnosti koriv-pervistok ukrainskykh chorno-riaboi ta chervono-riaboi molochnykh porid]. Visnyk Sumskoho natsionalnoho ahrarnoho universytetu. Seriia «Tvarynnytstvo», issue 1(40), pp. 11-16. doi: https://doi.org/10.32845/bsnau.lvst.2020.1.2

18. Khmelnychyi, L. M. and Vechorka, V. V., 2018. Vplyv otsinky liniinykh oznak typu, yaki kharakteryzuiut stan kintsivok, na tryvalist zhyttia koriv ukrainskykh chervono-riaboi ta chorno-riaboi molochnykh porid [Impact of assessment linear type traits that characterize condition of limbs, on the lifetime cows of Ukrainian Red-and Black-and-White dairy breeds]. Visnyk Sumskoho natsionalnoho ahrarnoho universytetu. Seriia «Tvarynnytstvo», issue 2(34), pp. 20-26.

19. Khmelnychyi, L. M. and Vechorka, V. V., 2017. Tryvalist zhyttia koriv ukrainskoi chervono-riaboi molochnoi porody zalezhno vid otsinky liniinykh oznak [Lifetime of cows of Ukrainian Red-and-White dairy breed depending on the assessment of linear traits]. Rozvedennia i henetyka tvaryn, issue 53, pp. 197-208.

20. Khmelnychyi, L. M. and Vechorka, V. V., 2015. Tryvalist zhyttia koriv ukrainskoi chorno-riaboi molochnoi porody v zalezhnosti vid rivnia liniinoi otsinky morfolohichnykh oznak vymeni [Lifetime cows of Ukrainian Black-and-White dairy breed depending on the level of linear assessment of udder morphological traits]. Naukovo-teoretychnyi zbirnyk Zhytomyrskoho natsionalnoho ahroekolohichnoho universytetu, issue 2(52), vol. 3, pp. 57-62.

21. Khmelnychyi, L. M., Vechorka, V. V. and Khmelnychyi, S. L., 2018. Osoblyvosti eksteriernoho typu molochnoi khudoby riznoho pokhodzhennia ta spivvidnosna minlyvist liniinykh oznak z nadoiem koriv holshtynskoi porody [Features of dairy cattle conformation type of different origin and relative variability of linear traits with milk yield of Holstein cows]. Rozvedennia $i$ henetyka tvaryn. Mizhvidomchyi tematychnyi naukovyi zbirnyk, issue 56, pp. 77-83.

22. Khmelnychyi, L. M. and Vechorka, V. V., 2020. Phenotypic consolidation of Brown cows by linear traits of conformation type [Fenotypova konsolidovanist koriv burykh porid za liniinymy oznakamy eksteriernoho typu]. Rozvedennia $i$ henetyka tvaryn. Kyiv, issue 59, pp. 168-174. https://doi.org/10.31073/abg.59.18

23. Khmelnychyi, L. M., Vechorka, V. V. and Khmelnychyi, S. L., 2020. Tryvalist zhyttia koriv ukrainskoi buroi molochnoi porody v zalezhnosti vid liniinoi otsinky morfolohichnykh oznak vymeni [Lifetime of Ukrainian Brown dairy cows depending on the linear assessment of udder morphological traits]. Tekhnolohiia vyrobnytstva i pererobky produktsii tvarynnytstva. Zbirnyk naukovykh prats Bilotserkivskoho DAU, issue 1(156), pp. 29-37.

24. Khmelnychyi, L. M., Kryvonos, Yu. O., Burnatnyi, S. V. and Samokhina, Ye. A., 2008. Kharakterystyka henealohichnykh ta zavodskykh linii buroi khudoby za molochnoiu produktyvnistiu [Characteristics of genealogical and stud lines of Brown cattle by milk productivity]. Visnyk Sumskoho NAU: seriia «Tvarynnytstvo», issue 10(15), pp.123-127.

25. Khmelnychyi, L. M., Ladyka, V. I., Polupan, Yu. P., and Salohub, A. M., 2008. Metodyka liniinoi klasyfikatsii koriv molochnykh i molochno-miasnykh porid za typom [The method of linear classification cows of dairy and dairy-beef breeds by type]. Sumy: "Mriya-1".

26. Alphonsus, C., Akpa G. N., Oni O. O., Rekwot P. I., Barje P. P., and Yashim S. M., 2010. Relationship of linear conformation traits with body weight, body condition score and milk yield in Friesian $\times$ Bunaji Cows, Journal of Applied Animal Research, issue 38(1), pp. 97-100.

27. Battagin, M., 2013. Genetic parameters for body condition score, locomotion, angularity, and production traits in Italian Holstein cattle. M. Battagin, C. Sartori, S. Biffani, M. Penasa, M. Cassandro. Journal of Dairy Science, June 3, Vol. 96, issue 8, pp. 5344-5351.

28. Daliri, Z., Hafezian S. H., Shad Parvar A. and Rahimi G., 2008. Genetic relationships among longevity, milk production and linear type traits in Iranian Holstein cattle. Journal of Animal and Veterinary Advances. Vol. 7, issue 4. pp. 512-515.

29. Getu, A. and Misganaw G. The role of conformational traits on Dairy cattle production and their longevities. Open Access Library Journal, 2: e1342.

30. Gibson, K. D., and C. D. Dechow. 2018. Genetic parameters for yield, fitness, and type traits in US Brown Swiss dairy cattle. J. Dairy Sci., issue 101(2), pp. 1251-1257.

31. ICAR Recording Guidelines approved by the General Assembly held in Berlin, Germany, on May 2014. Copyright: 2014, ICAR. 618 p.

32. Jovanovac, S., and N. Raguž., 2011. Analysis of the relationships between type traits and longevity in Croatian Simmental cattle using survival analysis. Agriculturae Conspectus Scientificus, issue 76(30), pp. 249-253. doi: https://hrcak.srce.hr/72046 10

33. Kern, E. L., Cobuci, J. A., Costa, C. N., Margaret, C. and Pimentel, M. M., 2014, Factor analysis of linear type traits and their relation with longevity in Brazilian Holstein cattle. Asian Australasian Journal of Animal Sciences. issue 27(6), pp.784-790.

34. Khan, M. A., 2016. Genetic parameters of udder traits and their relationship with milk yield in Sahiwal cows of Pakistan. Journal of Animal and Plant Sciences, issue 26(4), pp. 880-886. 
35. Koeck, A., Heringstad B., Egger-Danner C., Fuerst C., Winter P., Fuerst-Waltl B., 2010. Genetic analysis of clinical mastitis and somatic cell count traits in Austrian Fleckvieh cows. Journal of Dairy Science, issue 93, pp. 5987-5995.

36. Ladyka, V. I., Khmelnychyi, L. M. and Khmelnychyi, S. L., 2019. Conformation types of Brown cattle of Sumy region in Ukraine (Monograph). Lublin, $133 \mathrm{p}$.

37. Liu, S., H. Tan, L. and Yang, J. Yi. 2014. Genetic parameter estimates for selected type traits and milk production traits of Holstein cattle in southern China. Turk. J. Vet. Anim. Sci., issue 38, pp. 552-556.

38. Ptak, E., Jagusiak W., Zarnecki A. and Otwinowska-Mindur A. 2011. Heritabilities and genetic correlations of lactational and daily somatic cell score with conformation traits in Polish Holstein cattle. Czech Journal of Animal Science, issue 56, pp. 193200.

39. Satoła, A., Ptak, E.; Jagusiak, W., Otwinowska-Mindur, A. Genetic relationship of conformation traits with lactose percentage and urea concentration in milk of Polish Holstein-Friesian cows. Animal Science Papers \& Reports. 2017, Vol. 35, issue 3, p241-251.

40. Sewalem, A., Kistemaker, G. J. and Van Doormaal, B. J., 2005. Relationship between type traits and longevity in Canadian Jerseys and Ayrshires using a Weibull proportional hazards model. Journal of Dairy Science, Vol. 88, issue 4, pp.15521560.

41. Tapki, I. and Ziya, G. Y., 2013. Genetic and phenotypic correlations between linear type traits and milk production yields of Turkish Holstein dairy cows. Green. J. Agric. Sci., issue 3(11), pp. 755-761.

42. Zavadilová, L, Němcová, E., Štípková, M., 2011. Effect of type traits on functional longevity of Czech Holstein cows estimated from a Cox proportional hazards model. Journal of Dairy Science. Vol. 94. issue 8, pp. 4090-4099.

43. Zink, V., Zavadilová L., Lassen J., Štípková M., Vacek M., Štolc L., 2014. Analyses of genetic relationships between linear type traits, fat-to-protein ratio, milk production traits, and somatic cell count in first-parity Czech Holstein cows. Czech J. Anim. Sci., issue 59(12), pp. 539-547.

\section{Список використаної літератури:}

1. Буркат В. П., Котенджи Г. П., Ладыка В. И. Методы селекции лебединского скота на современном этапе. Матер. науч.-произв. конф.: Новые методы селекции и биотехнологии в животноводстве. К. 1991. С. 118-120.

2. Буркат, В. П., Полупан Ю. П., Йовенко І. В. Лінійна оцінка корів за типом. К.: Аграрна наука, 2004. 88 с.

3. Грінкевич Л. 3. Взаємозв'язок між продуктивністю і морфрофункціональними властивостями вимені корів голштинізованого типу червоної молочної породи. Таврійський науковий вісник. Херсон. 2004. Вип. 36. С. 101-104.

4. Ладика В. І. Методи створення, сучасний стан та шляхи подальшого удосконалення бурої молочної породи. Державна книга племінних тварин бурих порід великої рогатої худоби. К.: „ППНВ”. 2004. С. 38-46.

5. Ладика В. І., Павленко Ю. М., Сухарєва А. В. Вплив лінійної належності на рівень продуктивності корів української бурої молочної породи. Вісник Сумського НАУ: серія «Тваринництво». 2017. Вип. 7 (33). С. $72-77$.

6. Ладика В. І., Хмельничий Л. М. Особливості фенотипової різноманітності корів за екстер'єрним типом в аспекті збереження генофонду бурої худоби. Вісник Сумського НАУ: серія «Тваринництво». 2018. Вип. 2 (34). С. 3-10.

7. Ладика В. І., Хмельничий Л. М., Буркат В. П., Рубан С. Ю. Реєстрація ICAR. Довідник. Суми: Сумський національний аграрний університет, 2010. 457 c.

8. Ладика В., Котенджі Г., Рубцов І. та ін. Українська бура молочна порода. Тваринництво України. 2007. № 2. С. 3740. 10-11.

9. Ладика В., Хмельничий Л. Племінну оцінку - на загальнодержавний рівень. Тваринництво України. 2007. № 2. С.

10. Ладика, В. І. Стан та перспективи селекції бурої худоби. Вісник аграрної науки. 2000. №12. С. 84-86.

11. Меркурьева, Е. К. Генетические основы селекции в скотоводстве. М.: Колос, 1977. - 240 с.

12. Полупан Ю. П. Онтогенетичні та селекційні закономірності формування господарськи корисних ознак молочної худоби : дис. ... доктора с.-г. наук : 06.02 .01 / Ю. П. Полупан ; Ін-т розведення і генетики тварин НААН. с. Чубинське Київської обл., 2013. 694 с.

13. Полупан Ю. П., Коваль Т. П. Зв'язок морфологічних особливостей вим'я корів червоної молочної худоби з їхньою молочною продуктивністю. Вісник аграрної науки. 2006. № 11. С. 49-52.

14. Хмельничий Л. М. Успадковуваність та кореляційна мінливість лінійних ознак екстер'єру корів-первісток української червоно-рябої молочної породи Черкащини. Науково-інформаційний Вісник Херсонського державного аграрного університету. Херсон. 2018. Вип. 11. С. 73-75.

15. Хмельничий Л. М. Формування екстер'єрного типу корів української червоно-рябої молочної породи за використання бугаїв-плідників, оцінених за методикою лінійної класифікації. Вісник Сумського національного аграрного університету. Серія «Тваринництво». 2018. Вип. 2 (34). С. 10-20.

16. Хмельничий Л. М., Вечорка В. В. Вікова мінливість кореляцій між надоєм та лінійною оцінкою типу корів-первісток українських чорно- та червоно-рябої молочних порід. Технологія виробництва і переробки продуктів тваринництва. Збірник наукових праць БНАУ. Біла Церква. 2014. № 1 (116), С. 84-87.

17. Хмельничий Л. М., Вечорка В. В. Вплив лінійних ознак екстер'єру на стан молочної продуктивності корів-первісток українських чорно-рябої та червоно-рябої молочних порід. Вісник Сумського національного аграрного університету. Серія «Тваринництво». 2020. Вип. 1(40). C.11-16. DOI: https://doi.org/10.32845/bsnau.Ivst.2020.1.2 
18. Хмельничий Л. М., Вечорка В. В. Вплив оцінки лінійних ознак типу, які характеризують стан кінцівок, на тривалість життя корів українських червоно-рябої та чорно-рябої молочних порід. Вісник Сумського національного аграрного університету. Серія «Тваринництво». 2018. Вип. 2(34). С. 20-26.

19. Хмельничий Л. М., Вечорка В.В.Тривалість життя корів української червоно-рябої молочної породи залежно від оцінки лінійних ознак. Розведення і генетика тварин. 2017. Вип. 53. С. 197-208.

20. Хмельничий Л. М., Вечорка В.В.Тривалість життя корів української чорно-рябої молочної породи в залежності від рівня лінійної оцінки морфологічних ознак вимені. Науково-теоретичний збірник Житомирського національного агроекологічного університету. ЖНАЕУ. 2015. №.2 (52) Т. 3. С. 57-62.

21. Хмельничий Л. М., Вечорка В. В., Хмельничий С. Л. Особливості екстер'єрного типу молочної худоби різного походження та співвідносна мінливість лінійних ознак з надоєм корів голштинської породи. Розведення і генетика тварин. Міжвідомчий тематичний науковий збірник. 2018. Вип. 56. С.77-83.

22. Хмельничий Л. М., Вечорка В.В. Фенотипова консолідованість корів бурих порід за лінійними ознаками екстер'єрного типу. Розведення і генетика тварин. К. 2020. Вип. 59, С. 168-174. https://doi.org/10.31073/abg.59.18

23. Хмельничий Л. М., Вечорка В.В., Хмельничий С. Л. Тривалість життя корів української бурої молочної породи в залежності від лінійної оцінки морфологічних ознак вимені. Технологія виробництва і переробки продукції тваринництва. Збірник наукових праць Білоцерківського ДАУ. 2020. Вип. 1(156). С. 29-37.

24. Хмельничий Л. М., Кривонос Ю. О., Бурнатний С. В., Самохіна Є. А. Характеристика генеалогічних та заводських ліній бурої худоби за молочною продуктивністю. Вісник Сумського НАУ: серія «Тваринництво». 2008. Вип. 10 (15). С.123-127.

25. Хмельничий Л. М., Ладика В. І., Полупан Ю. П., Салогуб А. М. Методика лінійної класиффікації корів молочних і молочно-м'ясних порід за типом. Суми: ВВП “Мрія-1" ТОВ, 2008. с.

26. Alphonsus, C., Akpa G. N., Oni O. O., Rekwot P. I., Barje P. P., and Yashim S. M. Relationship of Linear Conformation Traits with Body weight, Body Condition Score and Milk yield ij Friesian × Bunaji Cows, Journal of Applied Animal Research, 2010. 38(1) : 97-100.

27. Battagin, M. Genetic parameters for body condition score, locomotion, angularity, and production traits in Italian Holstein cattle / M. Battagin, C. Sartori, S. Biffani, M. Penasa, M. Cassandro. // Journal of Dairy Science, 2013, June 3, Vol. 96, Issue 8, p $5344-5351$.

28. Daliri, Z., Hafezian S. H., Shad Parvar A., Rahimi G. Genetic Relationships among Longevity, Milk Production and Linear Type Traits in Iranian Holstein Cattle. Journal of Animal and Veterinary Advances. 2008. Vol. 7. Issue: 4. P. 512-515.

29. Getu, A. and Misganaw G. The role of conformational traits on Dairy cattle production and their longevities. Open Access Library Journal, 2: e1342.

30. Gibson, K. D., and C. D. Dechow. 2018. Genetic parameters for yield, fitness, and type traits in US Brown Swiss dairy cattle. J. Dairy Sci. 2015. 101(2): 1251-1257.

31. ICAR Recording Guidelines approved by the General Assembly held in Berlin, Germany, on May 2014. Copyright: 2014, ICAR. $618 p$.

32. Jovanovac, S., and N. Raguž. Analysis of the relationships between type traits and longevity in Croatian Simmental cattle using survival analysis. Agriculturae Conspectus Scientificus. 2011. 76(30): 249-253. doi: https://hrcak.srce.hr/72046 10

33. Kern, E. L., Cobuci J. A., Costa C. N., Margaret C., Pimentel M. M.. Factor analysis of linear type traits and their relation with longevity in Brazilian Holstein cattle. Asian Australasian Journal of Animal Sciences. 2014, 27(6):784-790.

34. Khan, M. A. Genetic parameters of udder traits and their relationship with milk yield in Sahiwal cows of Pakistan. Journal of Animal and Plant Sciences. 2016. 26(4):880-886.

35. Koeck, A., Heringstad B., Egger-Danner C., Fuerst C., Winter P., Fuerst-Waltl B. Genetic analysis of clinical mastitis and somatic cell count traits in Austrian Fleckvieh cows. Journal of Dairy Science, 2010.93, 5987-5995.

36. Ladyka, V. I., Khmelnychyi L. M., Khmelnychyi S. L. Conformation types of Brown cattle of Sumy region in Ukraine (Monograph). Lublin, 2019. 133 p.

37. Liu, S., H. Tan, L. Yang, J. Yi. Genetic parameter estimates for selected type traits and milk production traits of Holstein cattle in southern China. Turk. J. Vet. Anim. Sci. 2014. 38: 552-556.

38. Ptak, E., Jagusiak W., Zarnecki A., Otwinowska-Mindur A. Heritabilities and genetic correlations of lactational and daily somatic cell score with conformation traits in Polish Holstein cattle. Czech Journal of Animal Science, 2011. 56, $193-200$.

39. Satoła, A., Ptak, E.; Jagusiak, W., Otwinowska-Mindur, A. Genetic relationship of conformation traits with lactose percentage and urea concentration in milk of Polish Holstein-Friesian cows. Animal Science Papers \& Reports. 2017, Vol. 35 Issue 3, p241-251.

40. Sewalem, A., Kistemaker G. J., VanDoormaal B. J. Relationship Between Type Traits and Longevity in Canadian Jerseys and Ayrshires Using a Weibull Proportional Hazards Model. Journal of Dairy Science, 2005. Vol. 88, Issue 4, pp.1552-1560.

41. Tapki, I. And Ziya G. Y. Genetic and phenotypic correlations between linear type traits and milk production yields of Turkish Holstein dairy cows. Green. J. Agric. Sci. 2013. 3(11): 755-761.

42. Zavadilová, L, Němcová E., Štípková M. Effect of type traits on functional longevity of Czech Holstein cows estimated from a Cox proportional hazards model. Journal of Dairy Science. 2011. Vol. 94. Issue 8. pp. 4090-4099.

43. Zink, V., Zavadilová L., Lassen J., Štípková M., Vacek M., Štolc L. Analyses of genetic relationships between linear type traits, fat-to-protein ratio, milk production traits, and somatic cell count in first-parity Czech Holstein cows. Czech J. Anim. Sci., 2014. 59(12): 539-547. 
Хмельничий Леонтій Михайлович, доктор сільськогосподарських наук, профресор, Сумський національний аграрний університет (Суми, Україна)

Особливості екстер'єрного типу корів бурої худоби сумського регіону оцінених за методикою лінійної класифікації

Дослідження корів-первісток лебединської, української бурої молочної, бурої швіцької, оцінених за методикою лінійної класифрікації проведено на поголів"ї тварин Сумського регіону. Встановлена міжпородна мінливість за оцінкою 100бальної системи лінійної класифрікації та за 18 описовими ознаками 9-бальної шкали. Ознаки молочного типу краще виражені у корів швіцької породи (83,5 балу) проти 80,4 i 81,8 балу у ровесниць лебединської та української бурої молочної. Ознаки тулуба корів не відрізнялися істотною мінливістю при порівнянні піддослідних порід і знаходилися у межах похибки середньої величини (83,6-83,9 балу). Середня оцінка корів-первісток бурої швіцької породи за морфоологічними ознаками вимені на рівні 83,1 балу перевищувала оцінки тварин лебединської (80,4 балу) та української бурої молочної (81,8 балу) порід. Описові ознаки на відміну від групових відрізняються істотним рівнем мінливості, незалежно від оцінюваної породи. Встановлено високі та достовірні зв'язки між оцінкою групових ознак та величиною надою за першу лактацію, які характеризують молочний тип (0,222-0,433; ( $P<0,001)$, розвиток тулуба $(0,392-0,412 ; P<0,001)$ та вим'я $(0,364-0,484 ; P<0,001)$. Коефіцієнти кореляцій між фінальною оцінкою типу та надоєм становили у тварин піддослідних порід у межах 0,377$0,378(P<0,001)$. Додатна кореляція спостерігалася майже за усіма окремими описовими ознаками екстер'єру та надоєм у межах піддослідних порід за виключенням глибини вимені $(-0,119 \ldots-0,085)$, довжини дійок $(-0,044 \ldots-0,115)$ і вгодованості $(-$ 0,256...-0,303). За результатами лінійної оцінки корів бурих порід кращі показники екстер'єрного типу виявились у корів бурої швіцької породи, які характеризують ї̈ як спеціалізовану молочну. Лебединська худоба за ознаками лінійної класифікації наближається до комбінованого типу, а українська бура молочна займає проміжну позицію між оцінками лебединської та швіцької порід з характерними ознаками молочного типу.

Ключові слова: лебединська, українська бура молочна, бура швіцька, екстер'єрний тип, лінійна класифікація, кореляиія, тuп

Дата надходження до редакції: 02. 08.2020 р. 